\section{COMPARISON OF STRUCTURE OF MOUNTAINOUS ENVIRONMENTS OF LOCH CORUISK VALLEY (SKYE, SCOTLAND) AND THE FIVE LAKES VALLEY (THE TATRA MOUNTAINS)}

\title{
INTRODUCTION
}

Implementation of GIS methods in environmental research enables an efficient analysis of structure of environment, which is highly labour-intensive and quite troublesome while using traditional methods. This paper presents results achieved in a research carried out in two alpine environments: The Five Lakes Valley of The Polish Tatra Mountains and Loch Coruisk Valley, Skye, Scotland, conducted with the help of GIS and statistical methods. Analysis of structures of the rehearsed environments was based on recognition of pattern of geocomplexes, which allowed for: indication of dominant and subordinate, stable and fragile geocomplexes in researched ecosystems, determination of neighbourhood of geocomplexes, comparison of frequency and strength of relationships between geocomponents in different types of geocomplexes and assessment of biodiversity of the researched environments. Landscape pattern was used for elucidating geoecological processes and prediction of further environmental changes.

\section{SHORT CHARACTERISTICS OF AREAS OF INTEREST}

The Five Lakes Valley, located in The High Tatra covers an area of about $6 \mathrm{~km}^{2}$ while Loch Coruisk Valley in Cuillin Hills on Skye - a Scottish Island of Inner Hebrides - about $15 \mathrm{~km}^{2}$. Both researched valleys have been modelled during the last glacial period, so in spite of different climatic, geological, hydrological, biogeographical and biocenotical conditions they have an essential common feature: an alpine relief which determines a uniform way of functioning of the environments.

The High Tatra Mountains are eroded in acidic granite which intruded in the Carboniferous period; Cuillin Hills are composed mainly of Tertian 
intrusions: intermediate gabbro and ultrabasic peridotites. In humid climate granite weathers quickly producing round hills, but under climatic conditions prevailing in The Tatra Mountains it forms steep and rugged peaks. Gabbro and peridotites are extremely hard rocks and also form high and rugged peaks. Both valleys are placed within the alpine and montane zones and constitute typical glacial valleys: maximum height difference in Loch Coruisk Valley reaches $900 \mathrm{~m}$ and in The Five Lakes Valley - $650 \mathrm{~m}$. In general, Loch Coruisk Valley is steeper, less accessible and more rugged than the latter. Both areas of interest are considered as high mountain environments and appreciated by climbing and trekking tourists.

Quaternary deposits constitute an important differentiation of both valleys. In The Five Lakes Valley they cover $73 \%$ of the researched area (moraines $-36 \%$, slope deposits $-27 \%$ and alluviums $-10 \%$ ); in Loch Coruisk Valley $67 \%$ (34\%, $11 \%$ and $12 \%$ respectively). Despite the ultrabasic character or gabbro, its great resistance to weathering does not produce particularly basic soils. Generally poor soils (lithosols, regosols, rankers and podzols) prevail at both areas of interest. More fertile soils in The Five Lakes Valley developed on mylonites which formed as a result of tectonic crushes on ridge passes and in Loch Coruisk Valley - on ultrabasic peridotite and, marginally, on basic sills and dykes which cut gabbroic laccolith.

In both areas of interest surface waters are represented by alpine lakes and streams and underground waters by few moraine reservoirs and slotted waters. Due to impermeable ground, bogs and peats have developed at the very bottoms of both valleys at sites where runoff is impeded. However in more humid climate of Loch Coruisk Valley, bogs and peats dominate in the landscape while in The Five Lakes Valley they form small patches.

The most conspicuous feature differentiating the researched valleys is climate. The Tatra Mountains are placed in a moderate, transitional from atlantic to continental zone with cold winters and hot summers, precipitation peak during summer months (mean yearly precipitation reaches $1700 \mathrm{~mm}$ ), strong foehn winds and winter inversions of temperature. Geographical situation of Skye determines its cool, extremely atlantic climate with high precipitation all over the year (yearly precipitation averages $3400 \mathrm{~mm}$ ), strong winds and mild winters and summers leading to small temperature amplitudes $\left(37^{\circ} \mathrm{C}\right.$, while $58^{\circ} \mathrm{C}$ in The Tatra Mountains). Atlantic character of Loch Coruisk Valley is further emphasised by a fact that it is located in the southern part of Skye and opens straight to the sea, allowing easy penetration of the valley by humid, westerly winds. Skye climate can be characterised by its name which derives from the Norse "skuy" meaning "cloud", in Gaelic it is Eilan á Cheo - "Isle of mists" there are more than 300 rainy days in an average year.

The Five Lakes Valley is placed above tree line (the lowest point in the valley is The Great Lake - $1664 \mathrm{~m}$ a. s. 1.). Loch Coruisk Valley is also devoid of trees, although it reaches sea level. This is due to hard rock, steep slopes and mainly - exposure to strong winds and humid air masses from 
the sea. Main vegetation types on both areas of research are alpine meadows, grasslands and dwarf-shrub heaths, montane heaths and grasslands, fens, bogs, tall herb communities and scree and cliff communities. Some patches of subnival vegetation can be found at both sites. Both valleys have long been subjected to anthropopression (burning, tourism) and sheep grazing - its influence is depicted by introduction of anthropogenic communities and species.

\section{METHODS}

In the research, three components were acknowledged to be principal: geology, geomorphology (which determine the main processes in the ecosystem) and vegetation (which is an excellent indicator of all geocomponents). Small areas of fields of research, enormous variety of mountainous ecosystems and the aim of the research required a detailed study. Both case studies were carried out in 1:10 000 scale. Maps of slopes were produced by interpolation of contour maps and derivation of Digital Elevation Models. Finally slope maps were classified according to classification of mountainous relief proposed by T. Kalicki (1986). Maps of geology, slope inclination and vegetation were used for delimitation of homogenous units. Map algebra (overlaying) was carried out using simple but efficient GIS package - IDRISI. In effect a total of 40 types of geocomplexes, represented by more than 1400 individual units was created at both sites. The rank of the distinguished typological units is higher than facies but lower than uroczyskos. Maps of types of geocomplexes became base maps for statistical analysis of structure of the environments. Statistical methods require numerical data. Geocomplexes constitute qualitative characteristics of the environment. To quantify the data, three numerical parameters of geocomplexes were calculated: area, perimeter and number of individual land units in particular type of geocomplex. Calculation of these measurements was possible thanks to employment of GIS methods. As a result over 30 indicators were evaluated.

\section{STATISTICAL ANALYSIS OF ENVIRONMENTAL S'IRUCTURE}

Evaluated statistical indicators can be divided into four groups:

1. parameters of size and frequency of occurrence of land units:

- number of delimited types of geocomplexes,

- number of individual geocomplexes,

- mean area of types of geocomplexes,

- mean area of geocomplexes,

- mean perimeter of types of geocomplexes,

- mean perimeter of geocomplexes;

2. indicators of shape of land units (Pietrzak, 1989): 


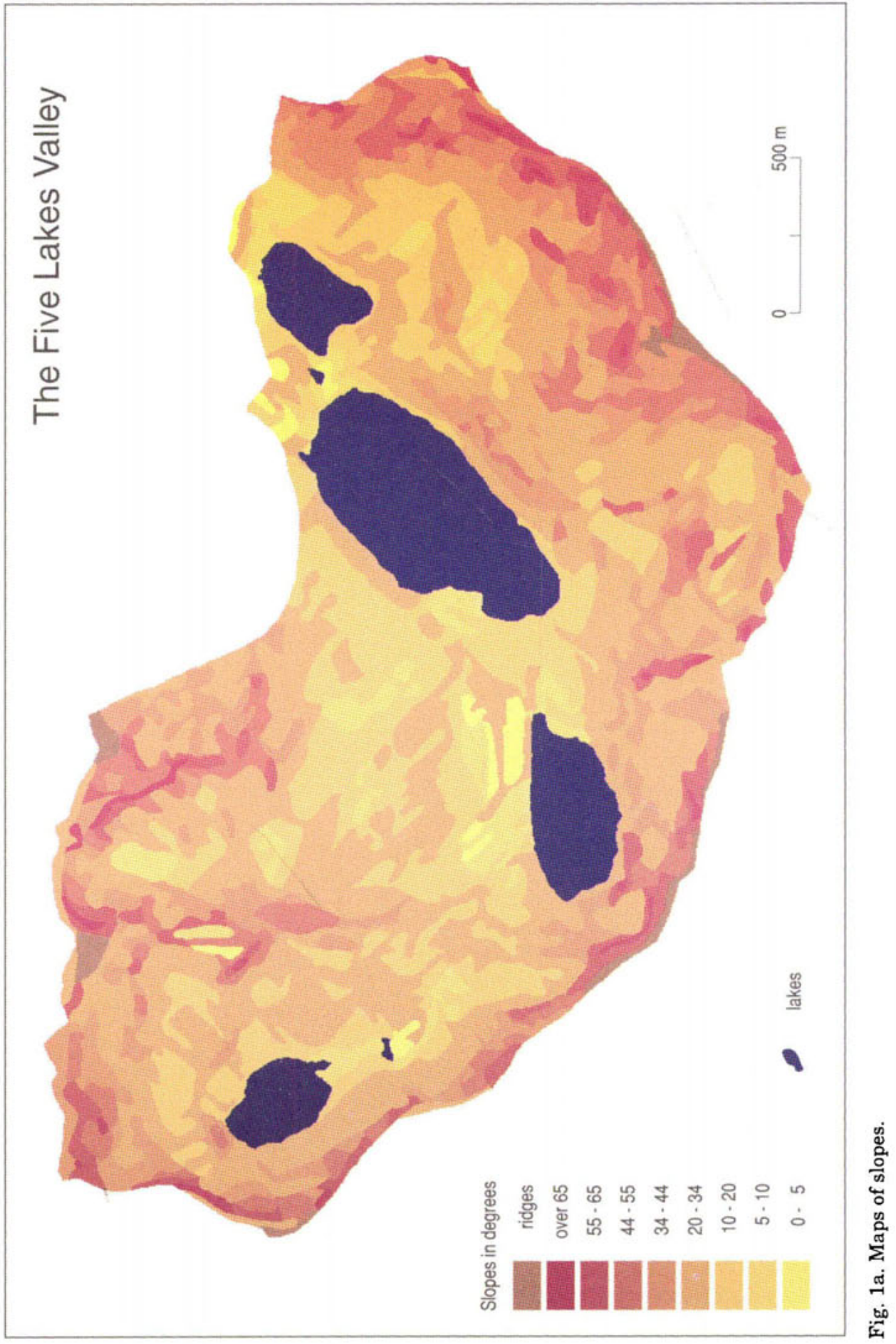




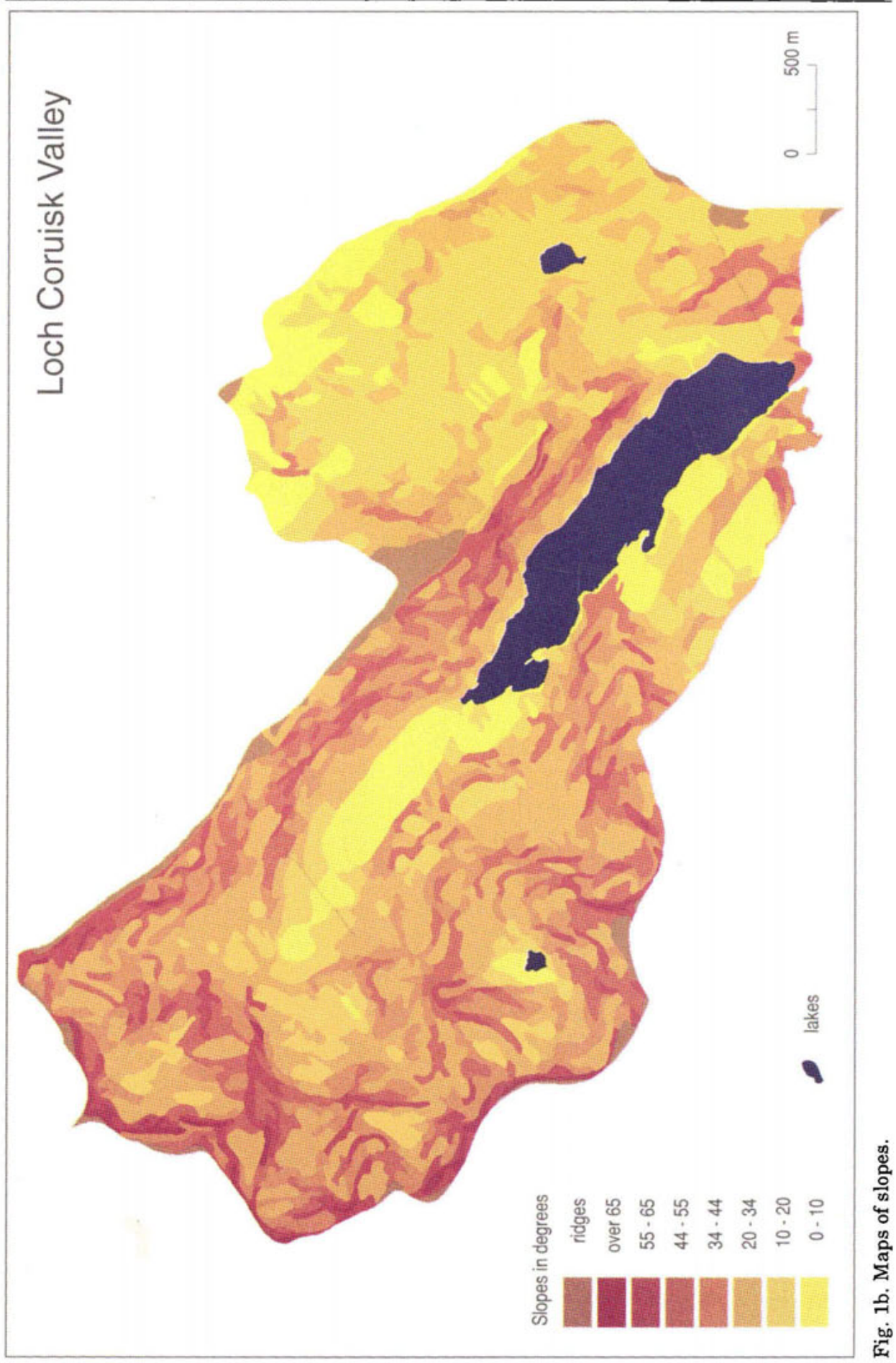




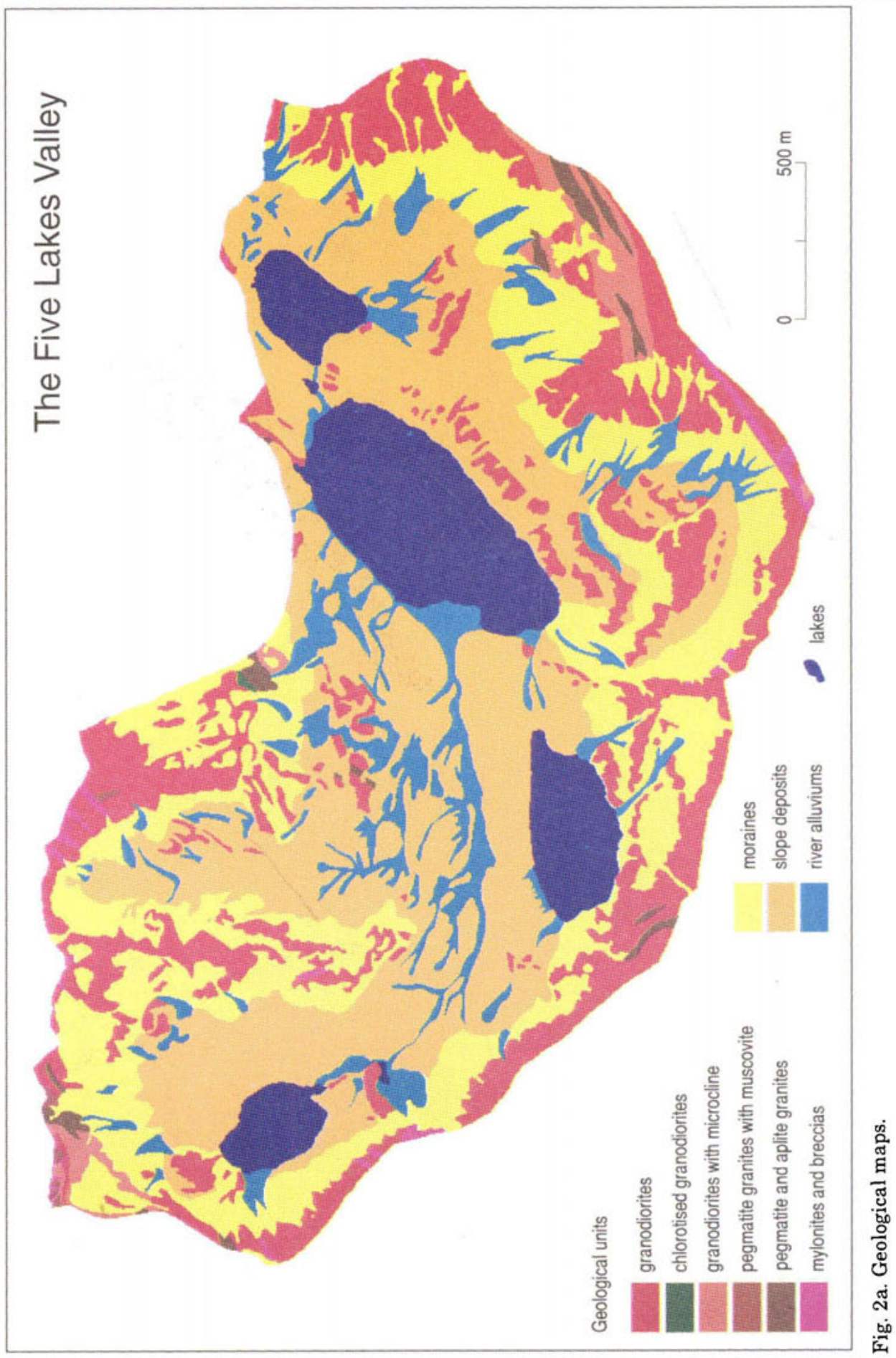




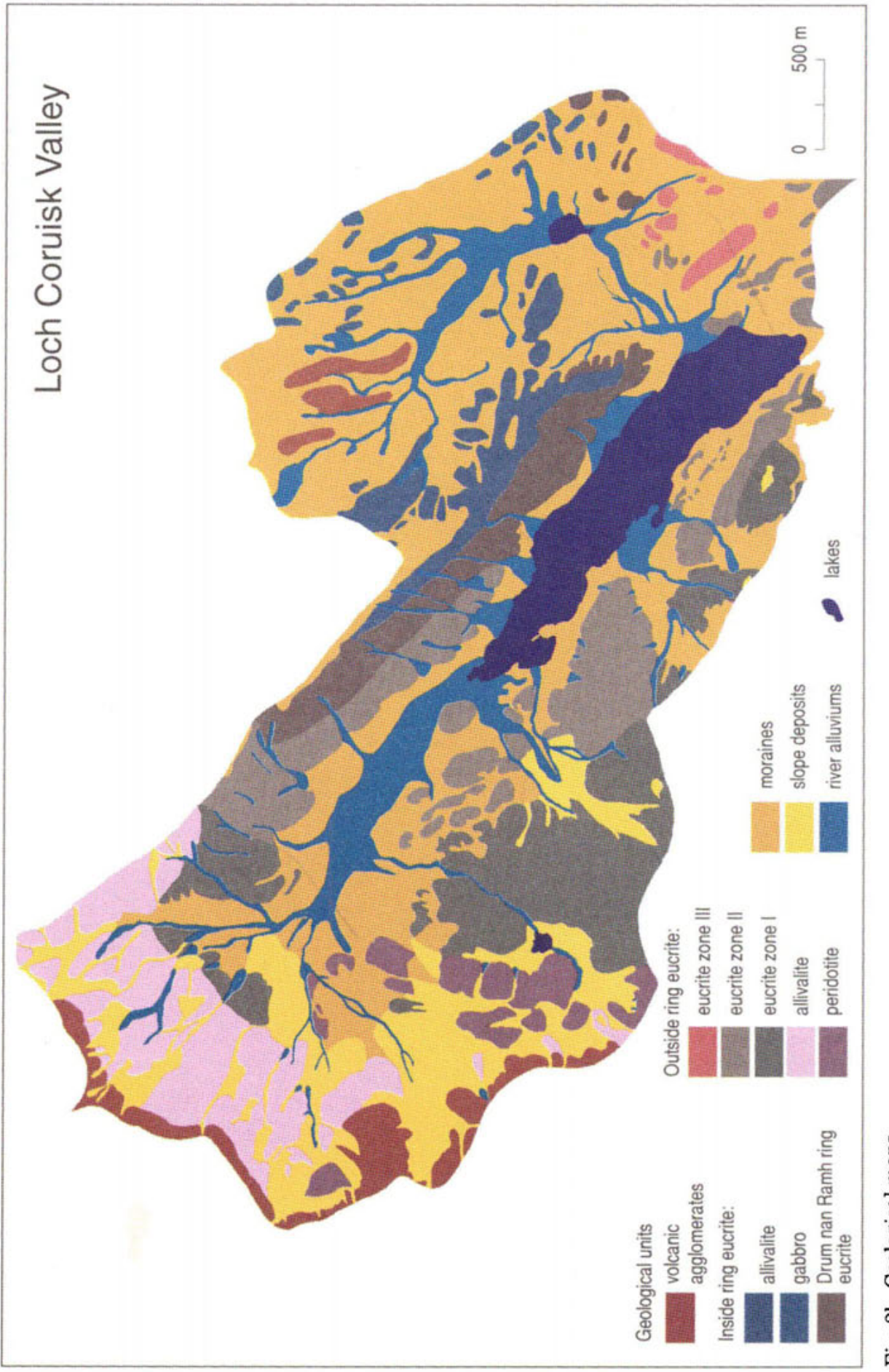

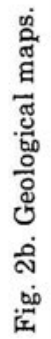




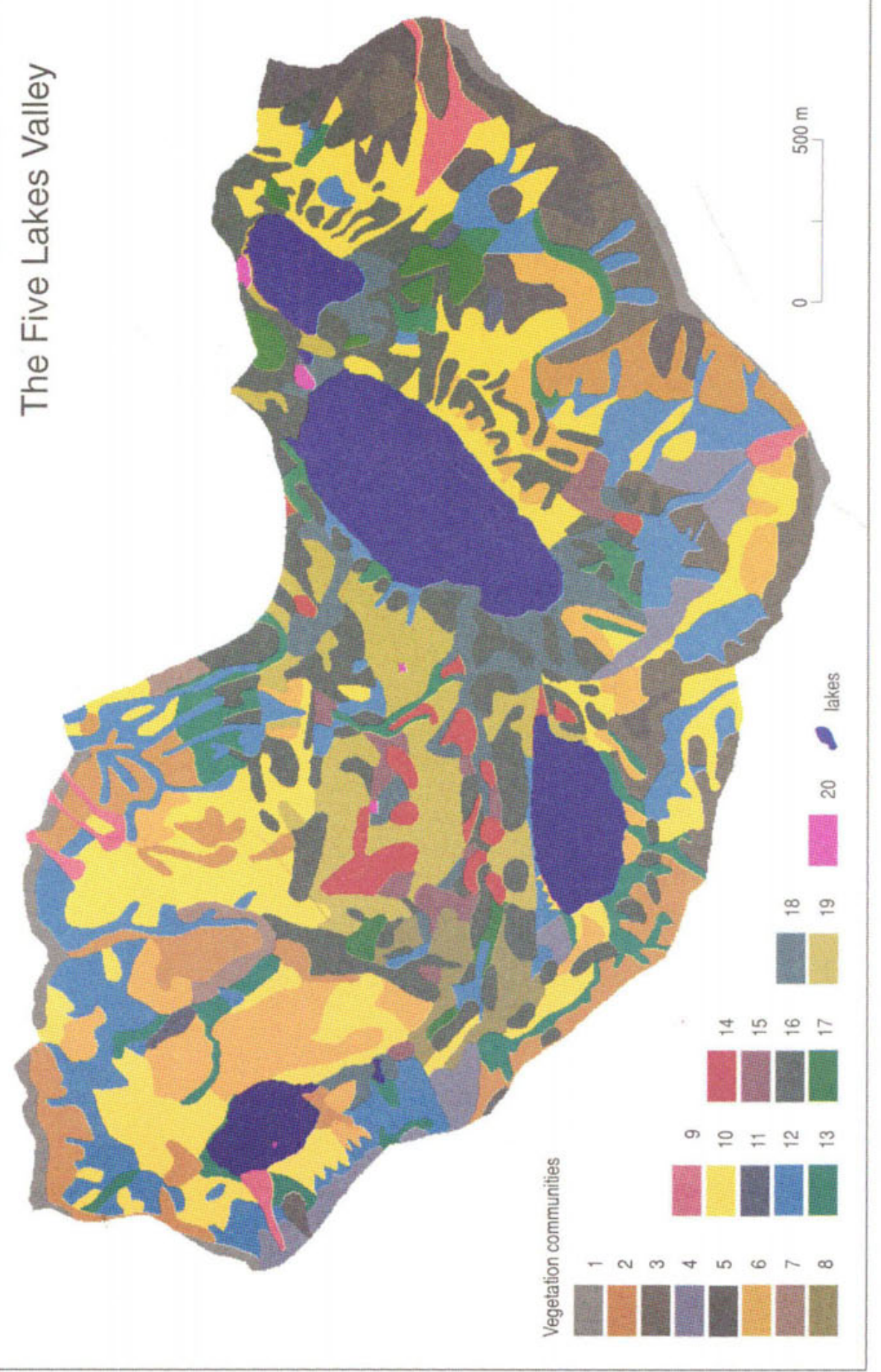

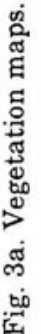




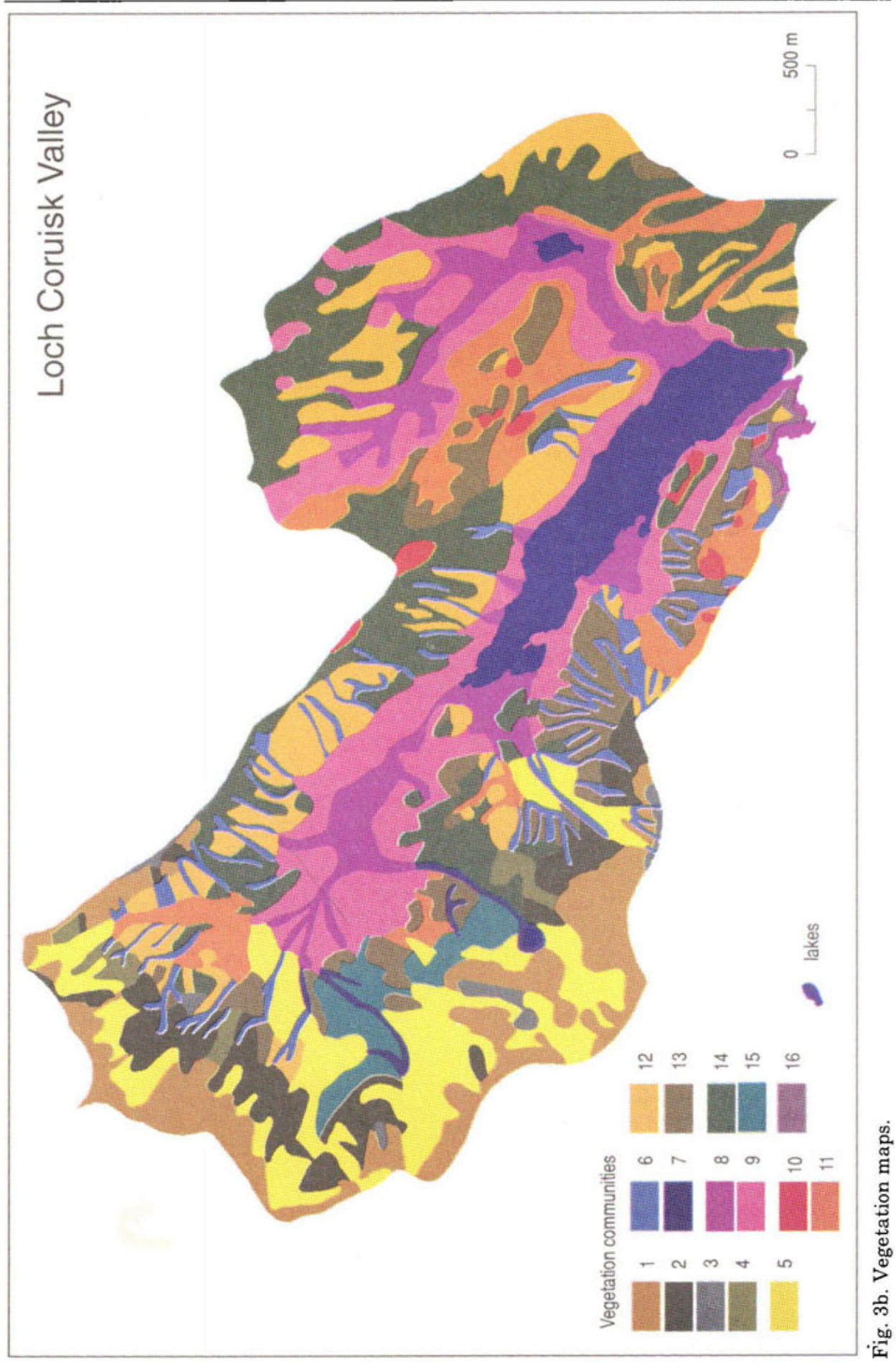


Vegetation communities of The Five Lakes Valley:

Subnival communities

1 - Minuartio-Oreochloetum distichae, Com. Oreochloa disticha-Gentiana frigida, Trifido-Distichetum subnival variant with Oreochloa disticha

Alpine meadows on granite

2 - Trifido-Distichetum typicum, $3-T$.-D. sphagnetosum, $4-T$. -D. salicetosum herbaceae, 5-T. -D. salicetosum kitaibelianae, Drepanoclado-Salicetum kitaibelianae,

$6-T$. -D. scree variant with Juncus Trifidus , $7-T$. -D. caricetosum sempervirentis,

$8-T$. - D. anthropogenic variant with Agrostis rupestris and Deschampsia flexuosa

Alpine meadows on mylonites

9 - Festuco versicoloris-Agrostietum alpinae, Com. with Silene cucubalus

Scree communities

10 - Rhizocarpetalia

Communities on long lasting snow cover terrain

11 - Salicetum herbaceae and mossy communities from Salicetea herbaceae,

12 - Luzuletum spadiceae

Tall herb communities

13 - Calamagrostietum villosae, Aconitetum firmi, Adenostyletum alliariae

Bogs and fens

14 - Com. with Eriophorum vaginatum, Sphagno-Nardetum, Shagno-Caricetum,

15 - Caricetum fuscae subalpinum

Dwarf-shrub heaths and shrubs

16 - Pinetum mughi carpaticum, 17 -Vaccinietum myrtylli, Empetro-Vaccinietum

Sheep-grazed communities

18 - Com. with Deschampsia flexuosa, Hieracio alpini-Nardetum, 19 - Cerastio fontaniDeschampsietum

Anthropogenic communities

20 - Com. with Stellaria media, Urtico-Aconitetum, Com. with Rumex obtusifolius, Com. with Cardaminopsis halleri, Com. with Ranunculus repens

\section{Vegetation communities of Loch Coruisk Valley:}

Alpine heaths and meadows

1 - Com. Festuca ovina-Luzula spicata, 2-Cariceto-Rhacomitretum lanuginosi,

3 - Rhacomitreto-Empetrum, 4 - Com. with Juniperus nana

Scree communities

5 - Rhizocarpetalia

Tall herb communities

6 - Com. Luzula sylvatica-Vaccinium myrtillus, 7 - Com. Sedum rosea-Alchemilla glabra

Fens

8 - Com. Carex rostrata-Scorpidium scorpioides, Com. Carex panicea-Campylium stellatum, Com. Eriophorum latifolium-Carex hostiana, Com. with Schoenus nigricans, 9 - Com. Trichophorum cespitosum-Carex panicea, Com. Molinia caerulea-Myrica gale Bogs

10 - Com. Eriophorum angustifiolium-Sphagnum cuspidatum, Trichophoreto-Callunetum, Trichophoreto-Eriophoretum, 11 - Molinieto-Callunetum

Dwarf-shrub heaths

12 - Callunetum vulgaris, 13 - Vaccinieto-Callunetum hepaticosum

Sheep-grazed communities

14 - Poor Agrosto-Festucetum, 15 - Rich Agrosto-Festucetum, Alchemilleto-AgrostoFestucetum

Coastal communities

16 - Com. Asplenium marinum-Grimma maritima 
- indicator of dismemberment of geocomplexes: $F=\frac{P}{2 \sqrt{\Pi A}}$,

— indicator of roundness of geocomplexes: $R_{c}=4 \Pi \frac{A}{P^{2}}$, [where $A-$ area of individual geocomplex, $\mathrm{P}$ - perimeter of individual geocomplex],

3. measures characterising spatial (horizontal) structure of geocomplexes:

- absolute entropy: $E=\sum_{i=1}^{n} p_{i} \log _{2} p_{i}$ [where: $p_{i}=\frac{s_{i}}{s}-$ probability of occurrence of particular state (the proportion of landscape in habitat $i$ or \% of geocomplexes within the whole researched area), $s_{i}$ - area of individual geocomplex within a type (or 1), $s$ - total area of a type (or number of individual units within a type), $n-$ number of observed individual units within a type], (Richling, 1992),

- relative entropy: $E_{w}=\frac{E}{E_{\max }}$ [where: $E_{\max }=\log _{2} n$ ], (Richling, 1992),

- dominance: $D=E_{\max }-E$ (Turner, 1989),

- indicator of landscape unity $I=1-E_{w}$, (Szajnowska, 1978),

- indicator of heterogeneity $\left[K_{n}=\frac{\sum_{i=1 j=i+1} \sum_{i} m_{i} m_{j}}{C_{n}^{2}}\right.$, where $C_{n}^{2}=\frac{n(n-1)}{2}, n-$ number of types of geocomplexes, $m_{i}=\frac{s_{i}}{s}, s_{i}-$ area of types of geocomplexes, $s$ - total area of the valley],

- indicator of likelihood (frequency of the nearest neighbour): $P=2 \frac{c}{a+b} \cdot 100 \%$ [where: $a(b)-$ total length of border of unit $a$ (and $b$ respectively), $c-$ total common length of border between units $a$ and $b$ ], (Richling, 1992);

4. measures characterising relationships between different features of geocomponents:

- indicator of strength of relationships between geocomponents: $W=\frac{P_{r g}}{P_{g}}$ when $P_{g}<P_{r}$ and $W=\frac{P_{r g}}{P_{r}}$ when $P_{g}<P_{r}$, [where: $P_{r g}-$ area or frequency of types of geocomplexes with $r$ type of vegetation and $g$ category of geology, $P_{r}$ - total area (or frequency) of geocomplexes with $r$ type of vegetation, $P_{g}-$ total area (or frequency) of geo-complexes with $g$ category of geologyl, (Richling, 1992; Bezkowska, 1986); 
- Pearson's indicator of relationship $P=\sqrt{\frac{\sum\left[\frac{\sum / n_{2}}{n_{1}}\right]-1}{\left(r_{1}-1\right)\left(r_{2}-1\right)}}$, where: $r_{1}, r_{2}-$ number of categories of the first and second component, $f-$ number of connections between analysed components (or area of types of geocomplexes with two features of the components), $n_{1}, n_{2}-$ total number of classes with the first or the second feature (or area of types of geocomplexes with the first or the second feature of the components)], (Aleksandrowa, 1975).

For comparison, where possible, indicators were calculated both on the base of areas and number of geocomplexes within a type. Additionally, for some of the indicators characterising size and shape geocomplexes, an index of variability for each type of geocomplex was calculated: $V=\frac{s}{\bar{x}} \cdot 100 \%$ [where: $s-$ standard deviation of area within geocomplex type, $\bar{x}$ - mean value of area within geocomplex type], (Bočarov, 1976). Specification of the means of the evaluated values of indicators for each geocomplex type for the Five Lakes Valley and Loch Coruisk Valley is presented in Table 1 (all values of measured indexes and parameters are given in: Kurnatowska, 1995).

Table 1

\begin{tabular}{|c|c|c|}
\hline Mean values of indicators & $\begin{array}{c}\text { The Five Lakes } \\
\text { Valley }\end{array}$ & $\begin{array}{l}\text { Loch Coruisk } \\
\text { Valley }\end{array}$ \\
\hline Number of delimited types of geocomplexes & 42 & 41 \\
\hline Number of individual geocomplexes & 1407 & 1442 \\
\hline Total researched area (sq. meters) & 5823934,33 & 14944730,10 \\
\hline $\begin{array}{l}\text { Total researched area without lake areas } \\
\text { (sq. meters) }\end{array}$ & 5200148,63 & 14023622,32 \\
\hline Mean area of types of geocomplexes (sq. meters) & 123813,06 & 342039,57 \\
\hline Mean area of geocomplexes (sq. meters) & 3695,91 & 9725,12 \\
\hline Mean perimeter of types of geocomplexes (meters) & 12162,40 & 20468,14 \\
\hline Mean perimeter of geocomplexes (meters) & 363,06 & 581,96 \\
\hline Indicator of area variation & 210 & 285 \\
\hline Indicator of perimeter variation & 126 & 162 \\
\hline Indicator of dismemberment of geocomplexes (WRK) & 1,91 & 2,18 \\
\hline Indicator of WRK variation & 29 & 33 \\
\hline Indicator of roundness of geocomplexes (WK) & 0,33 & 0,27 \\
\hline Indicator of WK variation & 42 & 52 \\
\hline $\begin{array}{l}\text { Indicator of strength of relationships between } \\
\text { geocomponents based on areas }\end{array}$ & 0,46 & 0,40 \\
\hline $\begin{array}{l}\text { Indicator of strength of relationships between } \\
\text { geocomponents based on frequencies }\end{array}$ & 0,48 & 0,38 \\
\hline Absolute entropy based on areas & 5,26 & 4,73 \\
\hline
\end{tabular}




\begin{tabular}{|l|r|r|}
\hline \multicolumn{1}{|c|}{ Mean values of indicators } & $\begin{array}{r}\text { The Five Lakes } \\
\text { Valley }\end{array}$ & $\begin{array}{c}\text { Loch Coruisk } \\
\text { Valley }\end{array}$ \\
\hline Absolute entropy based on frequencies & 5,00 & 4,84 \\
Relative entropy based on areas & 0,97 & 0,88 \\
Relative entropy based on frequencies & 0,93 & 0,90 \\
Indicator of landscape unity based on areas & 0,024 & 0,116 \\
Indicator of landscape unity based on frequencies & 0,072 & 0,095 \\
Dominance based on areas & 0,13 & 0,62 \\
Dominance based on frequencies & 0,39 & 0,51 \\
Indicator of heterogeneity & 0,9797 & 0,9646 \\
Pearson's indicator of relationship based on areas & 0,0128 & 0,0196 \\
Pearson's indicator of relationship on frequencies & 0,0136 & 0,0196 \\
Mean indicator of likelihood (frequency of the nearest & & \\
neighbour) & 3,92 & 5,03 \\
\hline
\end{tabular}

\section{INTERPRETATION OF RESULTS - COMPARISON OF THE RESEARCHED ALPINE VALLEYS}

The leading component, determining character of all other components in alpine environments is relief. Strong dependence on gravitation is expressed by elongated and strongly dismembered shapes of geocomplexes. The most elongated shapes are characteristic for geocomplexes which are under strongest influence of slope processes and water flow (geocomplexes of subnival and alpine zone and hydrogenic ones). At the same time these geocomplexes are least transformed by man and are characterised by high cohesion.

At both sites enormous diversity of environments was recognised (strong break up and dispersion of types of geocomplexes). High diversity of small areas is typical for alpine environments and results from a wide range of different scale factors e.g.: macro-, meso- and microclimate. However, diversity of the researched areas can be attributed to different factors. In The Five Lakes Valley the main factors differentiating vegetation and hence landscape are: height above sea level (climatic zoning) and meso- and micro-relief (slope inclination and aspect) which determine soil humidity and microclimate. In Loch Coruisk Valley extremely humid climate reduces influence of temperature and sun exposition and emphasises significance of slope exposure to humid air masses and strong winds. The effect of these humid conditions is blurring of the outlines of vertical climatic zoning: lack of trees within forest zone, lowering of communities typical for alpine zone as low as to the sea level, and in the conditions of low competition, descent of some alpine species to the bottom of the valley. Main factors influencing the researched landscapes are reflected in a wide range of typical vegetation communities: alpine meadows in The Five Lakes Valley and bogs and fens in Loch Coruisk Valley (see included maps). Geocomplexes with these communities constitute dominant geocomplexes in the researched land- 
scapes, and, being climax communities, are characterised by high cohesion and stability.

An interesting differentiation of the researched environments is differentiation of geology. Geocomplexes on basic geological formations (mylonites in The Tatra Mountains and peridotites on Skye) are unique and conspicuous in the landscape because of their proliferating basic flora dominated by herbal species with big flowers. Because both mylonites and peridotites are easily weathered, basic communities are endangered by degradation. This fact should be taken into account while planning tourist routes. Unfortunately, nearly all the basal habitats in The Five Lakes Valley are on the mountain passes, which are crossed by tourist routes. These areas are hence subject to strong tourist and water erosion. In The Five Lakes Valley a classic example of an alluvial cone cut by a deep and still widening corrasion gully, trampled by tourists can be observed.

Of main importance to landscape diversity are also geocomplexes of small area frequencies but large quantity frequencies (many small units within one type of geocomplex), which cut large, 'background' geocomplexes. These are mostly represented by geocomplexes with hydrophillic communities on river alluviums. Because of small areas their cohesity is low which means that they are fragile to slightest changes of any of the environmental factors determining their habitats.

One of the most important conclusions achieved in this part of research was confirmation of the fact, that detailed phytosociological studies can replace complex environmental research. This is due to the fact, that vegetation is a perfect indicator of all environmental characteristics of the habitat like geology, geomorphology, hydrology and microclimate. Abrupt discontinuities in vegetation are associated with abrupt discontinuities in the physical environment and vegetation patterns in space reflect general pattern of the landscape and can lead to general conclusions concerning ecological processes. This is a not a new conclusion but its confirmation is important, as in mountain environments detailed studies of microclimate or hydrology are hardly feasible. Detailed studies of vegetation, being comparatively easy method of research, can be considered as the most important method of research in so diversified ecosystems.

In spite of alpine character and low accessibility of the areas of research, both polygons have been subjected to anthropopression for many years. Sheep grazing and burning of shrub communities led to significant changes of environmental structure in both valleys. The most transformed areas in the Five Lakes Valley are montane zone and lower parts of alpine zone, where shrub and heath communities were replaced by meadow and sometimes even mossy communities. In Loch Coruisk Valley montane communities stretched down to forest climatic zone. Because of low competition even some montane species descended to lower parts of the valley. On both polygons man's activity led not only to disturbance of natural sequence of vegetation communities but also to unification of structure of montane 
zones. These parts of both valleys are less diversified; with large and cohesive geocomplexes. Apart from changes in proportion of natural communities, some of the communities are inhabited by lowland species, alien to the researched areas. Abandonment of burning and sheep grazing (establishment of National Park in the Tatra Mountains, and gradual climate cooling on Skye) led to gradual withdrawal of lowland and anthropogenic species. However, natural succession may last many years - in extreme cases natural communities may not return at all. For example heather encroachment in Scotland leads to soil acidification and in some cases to development of peat processes. In the Tatra Mountains grazed meadow communities form compacted sod where dwarf mountain pine (Pinetum mughi carpaticum) seedlings can not cut-trough. In these cases anthropogenic changes to environment are irreversible and lead not only to evident changes of real vegetation but also to permanent changes of habitats which in long run lead to changes of potential vegetation. Stability of geocomplexes with anthropogenic vegetation is confirmed by high values of indicators of strength between geocomponents.

Summarising, it can be concluded that subnival, alpine and low, hydrogenic parts of both valleys are characterised by strong diversity and dispersion of landscape, with long individual geocomplexes and strong relationships between geocomponents (cohesive and stable). Montane zone, being a transitional zone between alpine and forest zones includes many geocomplexes which are characteristic for both zones. As many communities reach their extreme habitats, higher diversity and lower stability of montane zone should be expected. Meanwhile, significant reduction of landscape diversity (large, cohesive geocomplexes) and strong relationships between geocomponents are observed. This is an evident result of intensive and long-term anthropopression. This fact confirms also a long acknowledged fact that slight, short-term human activity leads to landscape variation (for instance tourist routes), while strong and long-term activity leads to unification of landscapes.

\section{REFERENCES}

Aleksandrowa T.D., 1975, Statisticheskiye metody izucheniya prirodnych kompleksow (Statistical methods of research of geocomplexes), Moskwa.

Bezkowska G., Struktura i typy geokompleksów w środkowej części Niziny Poludniowowielkopolskiej (Structure and types of geocomplexes in the middle part of the Południowowielkopolska Lowland), Acta Geographica Lodziensia, nr 54, Ossolineum, Łódź.

Boča rov M.K., 1976, Metody statystyki matematycznej w geografii (Methods of mathematical statistics in geography), Warszawa, PWN.

Kalicki T., 1986, Funkcjonowanie geosystemów wysokogórskich na przykładzie Tatr (Functioning of alpine geosystems on the example of the Tatra Mountains), Prace Geograficzne, 67, Zeszyty Naukowe UJ, Kraków.

Kurnat ow ska A., 1995, Analiza struktury środowiska przyrodniczego wybranych terenów górskich [Dolina Pięciu Stawów Polskich i Dolina Loch Coruisk] $z$ 
wykorzystaniem Geograficznych Systemów Informacyjnych (The analysis of structure of environment of chosen mountain environments [The Five Lakes Valley and Loch Coruisk Valley] with the help of Geographic Information Systems: diploma project evaluated in the Institute of Geoecology, supervised by A. Richling), Warszawa.

Pietrzak M., 1989, Problemy $i$ metody badania struktury geokompleksu [na przy. ktadzie powierzchni modelowej Biskupice] (Problems and methods of geo-complex structure research [based on the Biskupice case study]), Poznań, UAM.

Richling A., 1992, Kompleksowa geografia fizyczna (Complex Physical Geography), Warszawa, PWN.

S zajnowska A., 1978, Zastosowanie entropijnych miar w analizie przestrzennej (Employment of entropy measures in spatial analysis), Przeglad Geograficzny, 50,2 , Warszawa, PWN.

Turner M.G., 1989, Landscape Ecology: The Effect of Pattern on Process, Annu. Rev. Ecol. Syst., 20, 171-97. 